Acta Botanica Brasilica - 30(2): 266-270. April-June 2016. (c) 2016 doi: 10.1590/0102-33062015abb0242

\title{
Notes on Junghuhnia [Agaricomycetes] in Brazil
}

\author{
Georgea Santos Nogueira-Melo"*, Carla Rejane de Sousa Lira', Leif Ryvarden² and Tatiana Baptista Gibertoni'
}

Received: September 16, 2015

Accepted: March 23, 2016

\begin{abstract}
Junghuhnia is a cosmopolitan genus of Agaricomycetes (Basidiomycota), mostly characterized by having a dimitic hyphal system and encrusted cystidia. The genus comprises 37 legitimate species, eight of which have been reported in Brazil. This study provides updated information about the diversity and distribution of Junghuhnia in Brazil by reporting J. semisupiniformis for the first time from South America, J. globospora from Brazil, J. carneola from northeastern Brazil and the state of Pará, J. nitida from the state of Pernambuco, and J. subundata from the state of Amazonas. Descriptions of J. semisupiniformis and J. globosbora, as well a key to the accepted species of Junghuhnia from Brazil, are provided.
\end{abstract}

Keywords: Amazon Forest, Atlantic Forest, Caatinga, Fungi, Polypores

\section{Introduction}

Brazil has a large territory mostly located in the intertropical zone and has a hot climate throughout the year. This allows a great diversity of ecosystems ranging from semi-desert to evergreen tropical rain forests. Brazil may be the richest country on earth in biological diversity (Mittermeier et al. 2005), including wood-inhabiting fungi. Currently, 5712 fungi are reported to Brazil and much of this fungal diversity is still being listed and constantly updated (http://www.floradobrasil.jbrj.gov.br/).

Junghuhnia is a cosmopolitan genus of Agaricomycetes (Basidiomycota) which causes a white rot. It is characterized by annual, resupinate, effused, rarely pileate basidiomata, a dimitic hyphal system, encrusted cystidia, and obovoid to cylindrical basidiospores (Spirin et al. 2007; Westphalen et al. 2012). The genus comprises 37 legitimate species (http:// www.indexfungorum.org/; Kirk et al. 2008), eight of which were reported in Brazil: Junghuhnia carneola, J. crustacea, J. meridionalis, J. minuta, J. nitida, J. polycystidifera, J. subundata and J. undigera (Baltazar \& Gibertoni 2009; Westphalen et al. 2010; Soares et al. 2014a; Gugliotta et al. 2015).

Recently, several studies including new species and new records of polypores in Brazil have been published (Baltazar et al. 2014; Baldoni et al. 2015; Campos-Santana et al. 2014; 2015; Motato-Vásquez et al. 2014; 2015a; b; Soares et al. 2014b; Westphalen et al. 2014; Pires et al. 2015), but few included species of Junghuhnia (Westphalen et al. 2010; 2012). In the current study, we present descriptions of $J$. semisupiniformis and J. globospora and a key to the accepted species of Junghuhnia reported in Brazil. In addition, an update of distribution of some species is provided.

\section{Materials and methods}

Specimens were collected in the Amazonic Forest in April 2013, in the Floresta Nacional de Humaitá (7³0'22”S; $63^{\circ} 1^{\prime} 15^{\prime \prime} \mathrm{W}$ ), in the State of Amazonas; in the Atlantic Rain Forest from March 2012 to September 2013 in five remnants in the Reserva Particular do Patrimônio Natural (RPPN) Frei

\footnotetext{
${ }^{1}$ Departamento de Micologia, Universidade Federal de Pernambuco, Av. Prof. Nelson Chaves s/n, 50760-420, Recife, PE, Brazil

${ }^{2}$ Department of Botany, University of Oslo, P.O. Box 1045, Blindern, N-0316, Oslo, Norway

* Corresponding author: geomycota@gmail.com
} 
Caneca (8'42'37'S; 3550'01' $W$ ) and one in the Reserva Biológica de Saltinho ( $8^{\circ} 39^{\prime} 18^{\prime \prime}$; $38^{\circ} 1^{\prime} 46^{\prime \prime} \mathrm{W}$ ), both in the State of Pernambuco; in the semi-arid region from April 2012 to March 2014 in Parque Estadual Mata do Pau-Ferro (06 $58^{\prime} 12^{\prime \prime} \mathrm{S}$; 35 $42^{\prime} 15^{\prime \prime} \mathrm{W}$ ), a remnant of montane forest in the State of Paraíba.

Specimens were analyzed macro- (shape, colour, hymenial surface) and micromorphologically (hyphal system, presence/absence and measurements of sterile structures and basidiospores). Slides were prepared with $5 \% \mathrm{KOH}$ (stained with 1\% aqueous phloxine) or Melzer's reagent in order to check for amyloid or dextrinoid reaction (Wu et al. 2004). Technical nomenclature followed Fidalgo \& Fidalgo (1967) and colour designation followed Watling (1969). For identification, the works of Ryvarden (1991; 2014), Ryvarden \& Gilbertson (1993) and Ryvarden \& Melo (2014) were utilized. Specimens were incorporated to Herbaria $\mathrm{O}$ and URM.

Additionally, reports of species of Junghuhnia Corda were surveyed in the databases Specieslink (http://www.splink. org.br/) and Lista de Espécies da Flora do Brasil (http:// floradobrasil.jbrj.gov.br/) and in the literature (Bononi 1992; Almeida-Filho et al. 1993; Sotão et al. 2002; Baltazar \& Gibertoni 2009; Gibertoni \& Drechsler-Santos 2010; Westphalen et al. 2010; Westphalen et al. 2012; Soares et al. 2014a).

\section{Results and Discussion}

\section{Overall diversity}

After field trips, research in the databases and literature, 12 species of Junghuhnia, distributed in 12 Brazilian states are recognized (Tab. 1). In this study, we report $J$. semisupiniformis for the first time from South America (in remnants of Atlantic Forest in the State of Pernambuco); J. globospora from Brazil; J. carneola for the first time from Northeast Brazil (in a montane forest in the State of Paraíba and remnants of Atlantic Forest in Pernambuco) and from the State of Pará (in Amazonic Forest); J. nitida from the State of Pernambuco (in remnant of Atlantic Forest) and $J$. subundata from the State of Amazonas (in Amazonic Forest).

\section{Taxonomy}

Junghuhnia semisupiniformis (Murrill) Ryvarden, Mycotaxon 23: 195 (1985) (Fig. 1A-C)

$\equiv$ Tyromyces semisupiniformis Murrill, Bull. New York Bot. Gard.8: 148 (1912).

Description: Basidiomata: annual, pileate to effusedreflexed, fan-shaped, pileus thin, flexible, papery, $3 \times 4 \times$ $0.2 \mathrm{~cm}$. Abhimenial surface: glabrous, azonate, cream to pale brownish yellow ( $3 c$ to 5 e). Hymenial surface pale ochraceus (9h). Pores: angular, thin walled, 5-6 per mm.
Context homogeneous, tube layer concolorous with pore surface, $1 \mathrm{~mm}$ thick. Hyphal system: dimitic, generative hyphae with clamps, hyaline, $2.5 \mu \mathrm{m}$ in diam., skeletal hyphae abundant, thick-walled, hyaline to pale yellow, non septate, $2-5 \mu \mathrm{m}$ in diam. Cystidia: abundant in the trama, thin to slightly thick-walled, cylindrical to clavate, apically encrusted, projecting into the hymenium, $70 \times 8 \mu \mathrm{m}$. Basidia: clavate, 4 sterigmata, $20 \times 5 \mu \mathrm{m}$. Basidiospores: smooth, negative in Melzer reagent, obovoid to subglobose, 4-4.5 $\times$ 3-3.5 $\mu \mathrm{m}$.

Distribution: This species is widely distributed in the Caribbean area and it is cited from Mexico, Italy, France and Germany (Bernicchia 2005). This is the first report from South America.

Material examined: BRAZIL, Pernambuco, Jaqueira, RPPN Frei Caneca, Mata Barragem das Moças, in decaying hard wood, 3 Jun 2012, leg. G. S. Nogueira-Melo NM158, det. L. Ryvarden (URM 82257); BRAZIL, Pernambuco, Jaqueira, RPPN Frei Caneca, Mata Serra do Quengo, in decaying hard wood, 17 May 2013, leg. G. S. Nogueira-Melo NM630, det. L. Ryvarden (URM 86554); BRAZIL, Pernambuco, Jaqueira, RPPN Frei Caneca, Mata Serra do Quengo, in decaying hard wood, 20 Jul 2013, leg. G. S. Nogueira-Melo NM704, det. L. Ryvarden (URM 87684).

Remarks: Junghuhnia semisupiniformis is characterized by a pileate basidiomata and the abundant cystidia in the trama. The specimens analyzed had thin- to slightly thickwalled walled cystidia, while Ryvarden \& Gilbertson (1993) described the cystidia as thick-walled. Of the pileate species reported in Brazil, J. minuta has the smallest basidiospores among the American pileate species of the genus (2.5-3 $\times$ 2-2.5 $\mu \mathrm{m}$ ), while J. undigera, with similar pore size (5-7 p/ $\mathrm{mm}$ ) and basidiospores shape (broadly ellipsoid to obovoid), has slightly larger basidiospores $(4-5 \times 3.5-4 \mu \mathrm{m})$ and few cystidia in the trama.

Junghuhnia globospora Iturr. \& Ryvarden, Synop. Fungorum. 27: 83 (2010)

Description: Basidiomata: annual, resupinate to effused-reflexed, adnate, flexible, $5 \times 7 \times 0.3 \mathrm{~cm}$. Hymenial surface: cream to pale yellowish ( $6 \mathrm{f}$ to $52 \mathrm{buff}$ ). Pores: angular, thin walled, 4-5 per mm. Context: concolorous with the pore surface, soft and up to $300 \mu \mathrm{m}$ thick, almost invisible to the naked eyes. Margin: very narrow, smooth, reflexed when dry, concolorous with the pore surface. Hyphal system: dimitic, generative hyphae with clamps, 2.5-3 $\mu \mathrm{m}$ in diam., thin-walled, skeletal hyphae thick-walled, hyaline, non septate, 2-3 $\mu \mathrm{m}$ in diam. Cystidia: abundant in the trama, thick-walled, cylindrical to club-like, smooth or with few crystals at the top, 40-60 × 6-8 $\mu \mathrm{m}$. Basidia: clavate, 4 sterigmata, basal clamp, 12-15 × 3-4 $\mu \mathrm{m}$. Basidiospores: smooth, negative in Melzer reagent, globose, hyaline, thinwalled, 4-5 $\mu \mathrm{m}$ diam.

Distribution: This species was known only from the type locality in Venezuela (Ryvarden \& Iturriaga 2010). The current report is the first from Brazil. 


\section{Georgea Santos Nogueira-Melo, Carla Rejane de Sousa Lira, \\ Leif Ryvarden and Tatiana Baptista Gibertoni}

Table 1. Brazilian records of species of Junghuhnia based on field trips, databases and literature records with locale of occurrence and voucher (not studied)/reference. $\mathrm{AC}=$ Acre; $\mathrm{AL}=$ Alagoas; $\mathrm{AM}=$ Amazonas; $\mathrm{AP}=$ Amapá; $\mathrm{BA}=\mathrm{Bahia} ; \mathrm{CE}=\mathrm{Ceará} ; \mathrm{PA}=\mathrm{Pará} ; \mathrm{PB}$ = Paraíba; PE = Pernambuco; PR = Paraná; RS = Rio Grande do Sul; SC = Santa Catarina; $S P$ = São Paulo.

\begin{tabular}{|c|c|c|c|}
\hline Species & State & Reference or voucher & Biome \\
\hline \multirow{4}{*}{ Junghuhnia carneola (Bres.) Rajchenb. } & $\mathrm{PB}$ & Present study & Caatinga \\
\hline & $\mathrm{AM}$ & INPA 129588 & \\
\hline & PA & Present study & Amazonic Forest \\
\hline & $\begin{array}{c}\text { PR, RS, SC } \\
\text { SP }\end{array}$ & $\begin{array}{l}\text { Westphalen et al. (2012) } \\
\text { SP-Fungi } 446259\end{array}$ & Atlantic Forest \\
\hline \multirow{3}{*}{ Junghuhnia crustacea (Jungh.) Ryvarden } & & Bononi (1992) & Amazonic Forest \\
\hline & $\mathrm{AM}$ & INPA 185882 & \\
\hline & PA & Sotão et al. (2002) & Amazonic Forest (mangrove) \\
\hline Junghuhnia globospora Iturr. \& Ryvarden & $\mathrm{PB}$ & Present study & Caatinga \\
\hline Junghuhnia lacera (P. Karst.) Niemelä \& Kinnunen & SP & $\begin{array}{c}\text { INPA } 186302 \\
\text { (as J. separabilina) }\end{array}$ & $\begin{array}{l}\text { Atlantic Forest - Cerrado } \\
\text { (transition zone) }\end{array}$ \\
\hline Junghuhnia luteoalba (P. Karst.) Ryvarden & SP & Gugliota et al. (2015) & Cerrado \\
\hline \multirow{2}{*}{ Junghuhnia meridionalis (Rajchenb.) Rajchenb. } & PR, RS, SC & Westphalen et al. (2010) & \multirow{2}{*}{ Atlantic Forest } \\
\hline & SP & SP-Fungi 446273 & \\
\hline Junghuhnia minuta I. Lindblad \& Ryvarden & PR, RS, SC & Westphalen et al. (2012) & Atlantic Forest \\
\hline Junghuhnia nitida (Pers.) Ryvarden & $\begin{array}{c}\text { SP } \\
\text { AL, PR, RS, SP } \\
\text { PE }\end{array}$ & $\begin{array}{c}\text { SP-Fungi } 446222 \\
\text { Baltazar \& Gibertoni (2009) } \\
\text { Present study }\end{array}$ & Atlantic Forest \\
\hline Junghuhnia polycystidifera (Rick) Rajchenb. & PR, RS, SC & Westphalen et al. (2012) & Atlantic Forest \\
\hline Junghuhnia semisupiniformis (Murrill) Ryvarden & $\begin{array}{l}\text { SP } \\
\text { PE }\end{array}$ & $\begin{array}{c}\text { Almeida-Filho et al. (1993) } \\
\text { Present study }\end{array}$ & $\begin{array}{c}\text { Atlantic Forest (mangrove) } \\
\text { Atlantic Forest }\end{array}$ \\
\hline Junghuhnia subundata (Murrill) Ryvarden & $\begin{array}{l}\mathrm{AM} \\
\mathrm{AP}\end{array}$ & $\begin{array}{l}\text { Present study } \\
\text { Soares et al. (2014b) }\end{array}$ & Amazonic Forest \\
\hline \multirow{3}{*}{ Junghuhnia undigera (Berk. \& M.A.Curtis) Ryvarden } & $\begin{array}{l}\mathrm{CE} \\
\mathrm{PE}\end{array}$ & $\begin{array}{l}\text { URM } 80473 \\
\text { URM } 80666\end{array}$ & Caatinga \\
\hline & $\mathrm{PA}, \mathrm{PR}, \mathrm{RS}, \mathrm{SC}, \mathrm{SP}$ & Westphalen et al. (2012) & $\begin{array}{c}\text { Amazonic Rain Forest, } \\
\text { Atlantic Forest }\end{array}$ \\
\hline & SP & Gibertoni \& Drechsler-Santos (2010) & Cerrado \\
\hline
\end{tabular}

Material examined: BRAZIL, Paraíba, Areia, Reserva Estadual Mata do Pau-Ferro, in decaying hard wood, 16 Apr 2012, leg. C.R.S. Lira CL627, det. L. Ryvarden (URM 87963).

Remarks: Junghuhnia globospora is characterised by the papery, thin and flexible basidiomata and globose basidiospores. Junghuhnia subundata is quite similar, but has smaller, subglobose to broadly ellipsoid basidiospores $(2.3-3 \times 2-2.5 \mu \mathrm{m})$ and the pore surface is ochre to pale brownish when dry (Ryvarden \& Iturriaga 2010).

Junghuhnia carneola (Bres.) Rajchenb., Revta Investnes agrop. Sér. 5 19(1): 45 (1984)

三 Poria carneola Bres., Hedwigia 35(5): 282 (1896).

Description: Westphalen et al. (2012)

Distribution: Tropical and subtropical species. In Brazil, reports are known for the States of Amazonas, Paraná, Santa
Catarina and Rio Grande do Sul (Baltazar \& Gibertoni 2009; Gugliotta et al. 2015). It is the first record for the State of Pará, Brazilian Northeast and Caatinga Biome.

Material examined: BRAZIL, Pará: Melgaço, Estação Científica Ferreira Penna August 2008, leg. T.B. Gibertoni s.n., det., L. Ryvarden (URM 79633); Paraíba: Areia, Parque Estadual Mata do Pau Ferro, in decaying hardwood, 29 April 2013, leg. C.R.S. Lira CL574, det. L. Ryvarden (URM 87642); Pernambuco, Jaqueira, RPPN Frei Caneca, Mata Guaribas, in litter, 9 Mar 2013, leg. G. S. Nogueira-Melo NM506, det. L. Ryvarden (URM 86408); Pernambuco, Jaqueira, RPPN Frei Caneca, Mata Barragem das Moças, in decaying hard wood, 20 Apr 2013, leg. G. S. Nogueira-Melo NM630, det. L. Ryvarden (URM 86409); Pernambuco, Recife: Parque 

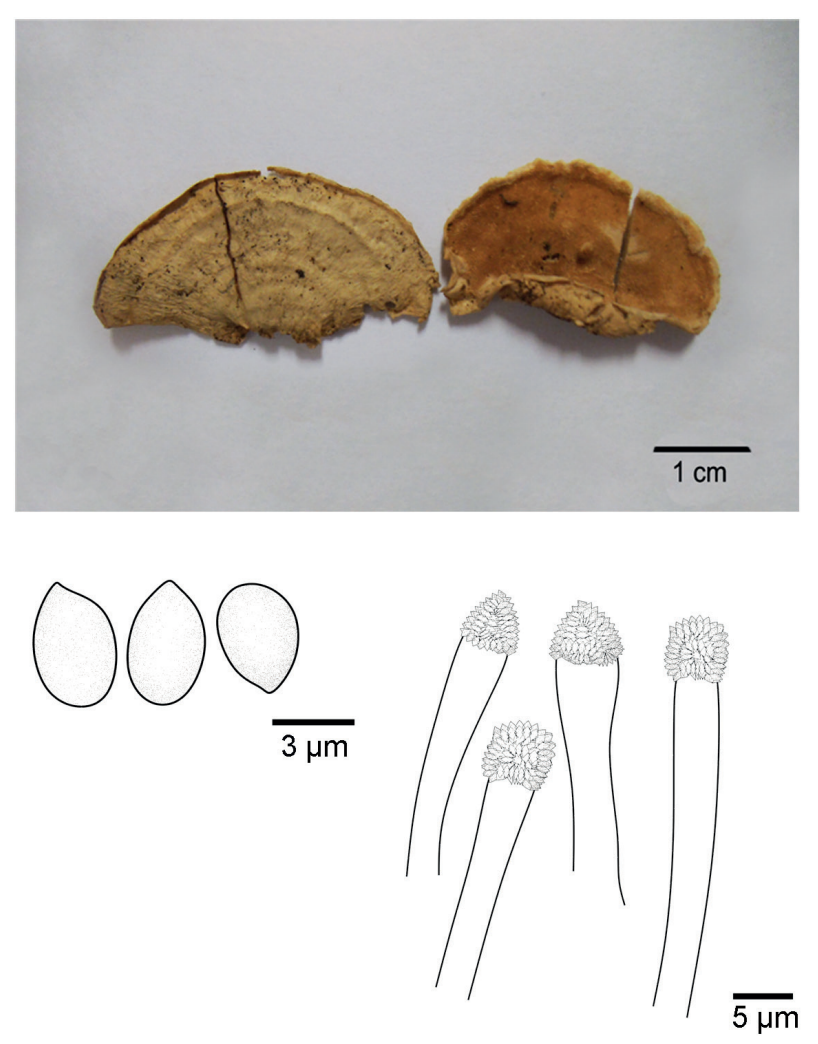

Figure 1. A. Basidiomata of Junghuhnia semisupiniformis. B. Encrusted tips of cystidia. C. Basidiospores
Estadual Dois Irmãos, in decaying hardwood, 18 May 2013, leg. R. Chikowski RC001, det. T. B. Gibertoni (URM 87694).

Remarks: This species is easily recognized because of the citric yellow basidiomata becoming reddish when bruised in fresh conditions (Westphalen et al. 2012).

Junghuhnia nitida (Pers.) Ryvarden, Persoonia 7(1): 18 (1972) $\equiv$ Poria nitida Pers., Observ. mycol. (Lipsiae) 2: 15 (1800) [1799]

Description: Ryvarden (2014)

Distribution: Cosmopolitan species (Ryvarden \& Melo 2014). In Brazil, reports are known for the states of Alagoas, São Paulo and Rio Grande do Sul (Gugliotta et al. 2015). This is the first time the species has been found in the state of Pernambuco.

Material examined: BRAZIL. PERNAMBUCO: Jaqueira, Reserva de Patrimônio Natural Frei Caneca, Mata Barragem das Moças, 26.VII.2012, leg. G.S. Nogueira-Melo et al. NM271, det. L. Ryvarden (URM 86410); Ibid, IX.2013, leg. G.S. Nogueira-Melo et al. NM333, det. L. Ryvarden (URM 86524); Recife, Parque Estadual Dois Irmãos, Açude do Prata, s.d., leg. T.B.S. Gibertoni, det. L. Ryvarden (URM 76811); Ibid, s.d. leg. T.B.S. Gibertoni, det. L. Ryvarden (URM 76812).

Remarks: The diagnostic characters of J. nitida are the pinkish cinnamon pore surface, the abundant encrusted, thick-walled cystidia, and the ovoid to broadly ellipsoid basidiospores (4-4.5 × 2-2.5 $\mu \mathrm{m}$ ) (Ryvarden \& Melo, 2014; Westphalen et al. 2012).

\section{Key to the species of Junghuhnia recorded in Brazil}

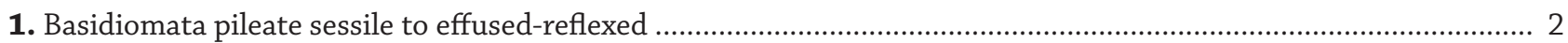

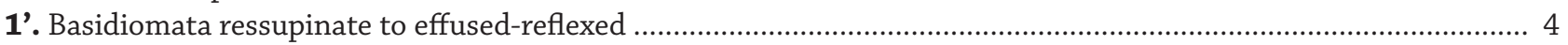

2. Pileus dimidiate to almost laterally stipitate ................................................................................... J. undigera

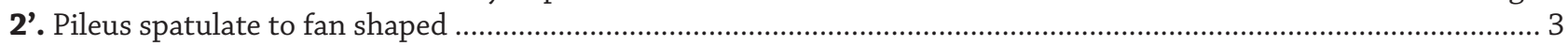

3. Basidiospores ellipsoid to subglobose, $2.5-3 \times 2-2.5 \mu \mathrm{m} \mathrm{n................................................................................} \mathrm{J.} \mathrm{minuta}$

3'. Basidiospores ellipsoid to obovoid, 3.5-4.5 × 3-3.5 $\mu \mathrm{m}$................................................................. J. semisupiniformis

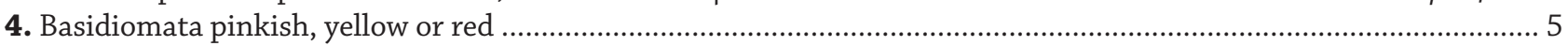

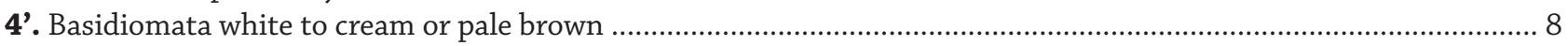

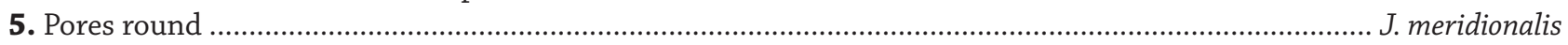

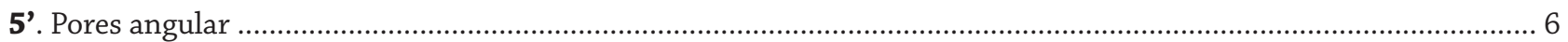

6. Hymenial surface chrome yellow when fresh, becoming reddish when bruised ........................................ J. carneola

6'. Hymenial surface ochraceous buff or pale buff to pinkish buff or pinkish cinnamon ............................................ 7

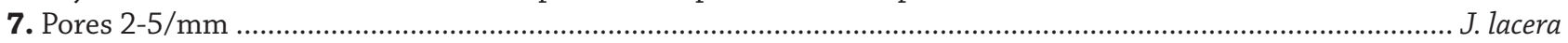

7'. Pores $5-7 / \mathrm{mm}$............................................................................................................................................ J. nitida

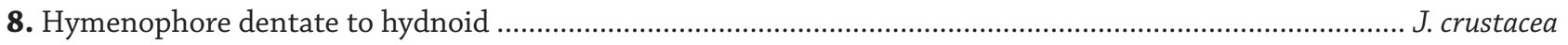

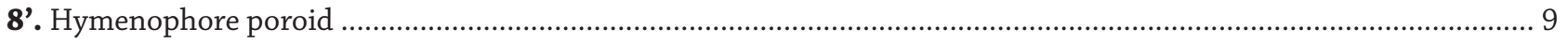

9. Pores minute, invisible to naked eye, $7-9 / \mathrm{mm}$.................................................................................. J. subundata

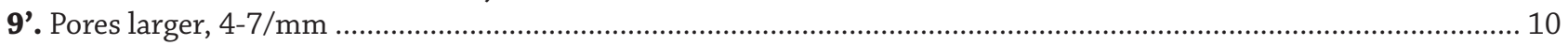

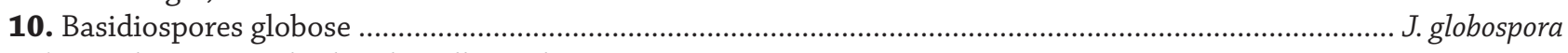

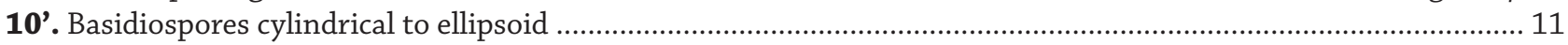

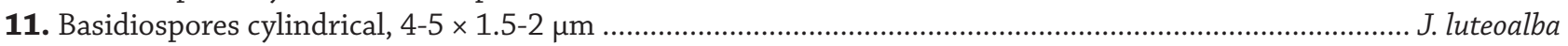

11'. Basidiospores ellipsoid to subcylindrical, $2.5-3.5 \times 1.0-1.5 \mu \mathrm{m}$.................................................... J. polycystidifera 
Junghuhnia subundata (Murrill) Ryvarden, Synop. Fungorum 32: 61 (2014)

$\equiv$ Poria subundata Murrill, Mycologia 13(2): 86 (1921).

Description: Ryvarden (2014)

Distribution: Pantropical. Neotropical specimens have been seen from Puerto Rico, Costa Rica and Panama (Ryvarden 2014) and, in Brazil, reported in the State of Amapá (Soares et al. 2014a) and now from Amazonas. Other reports of J. subundata in Brazil were considered as dubious by Westphalen et al. (2012).

Material examined: BRAZIL, Amazonas, Humaitá, Floresta Nacional de Humaitá, in decaying hardwood, 23 Apr 2013, leg. A. Gomes-Silva AC167, det. L. Ryvarden (URM 87641).

Remarks: Junghuhnia subundata is mainly characterized by the tiny pores (7-9 per $\mathrm{mm}$ ) and minute, subglobose to broadly ellipsoid basidiospores $(2.5-3 \times 2.5-4 \mu \mathrm{m})$. The size of the basidiospores separates it from the other resupinate species described in the genus. The occurrence of cystidia is apparently variable: sometimes, they are easily observed, while in other specimens they are difficult to find (Ryvarden 2014)

\section{Acknowledgments}

We thank the managers and staff of RPPN Frei Caneca for support during the field trips; Michael Finnie and Miles Hudson for English improvements; Dr. Roger Melo, for help with figures; the Programa de Pós-Graduação em Biologia de Fungos (UFPE, Brazil) and Conselho Nacional de Desenvolvimento Científico (CNPq) [SISBIOTA (563342/2010-2), PPBio Semi-Árido (457476/2012-5), PROTAX (562106/2010-3), Universal (472792/2011-3)] for financial support, and to Coordenação de Aperfeiçoamento de Pesquisa e Ensino Superior (CAPES) for the scholarship of GSNM and CRSL.

\section{References}

Almeida-Filho OM, Bueno R, Bononi VLR. 1993. Algumas espécies de fungos basidiomicetos dos manguezais do Estado de São Paulo. Hoehnea 20: 87-92.

Baldoni DB, Ortiz-Santana B, Coelho G, Antoniolli ZI, Jacques RJS. 2015. Sarcoporia polyspora (Basidiomycota, Polyporales): a rare wood-decay fungus newly recorded from South America. Nova Hedwigia 100: 177-187.

Baltazar JM, Gibertoni TB. 2009. A checklist of the aphyllophoroid fungi (Basidiomycota) recorded from the Brazilian Atlantic Forest. Mycotaxon 109: 439-442.

Baltazar JM, Ryvarden L, Gibertoni TB. 2014. Diplomitoporus (Polyporales, Basidiomycota) in Brazil revisited. Mycological Progress 13: 313-319.

Bernicchia A. 2005. Polyporaceae s.l. Fungi europaei 10. Alassio, Edizioni Candusso.

Bononi VLR. 1992. Fungos Macroscópicos de Rio Branco, Acre, Brasil. Hoehnea 19: 31-37.
Campos-Santana M, Amalfi M, Robledo G, Silveira RMB, Decock C. 2014. Fomitiporia neotropica, a new species from South America evidenced by multilocus phylogenetic analyses. Mycological Progress 13): 601-615.

Campos-Santana M, Robledo G, Decock C, Silveira RMB. 2015. Diversity of the poroid Hymenochaetaceae (Basidiomycota) from the Atlantic Forest and Pampa in Southern Brazil. Cryptogamie Mycologie 36: 43-78.

Fidalgo O, Fidalgo MEPK. 1967. Dicionário Micológico. São Paulo, Rickia. Gibertoni TB, Drechsler-Santos ER. 2010. Lignocellulolytic Agaricomycetes from the Brazilian Cerrado biome. Mycotaxon 111: 87-90.

Gugliotta AM, Gibertoni TB, Drechsler-Santos ER, et al. 2015. Polyporales in Lista de Espécies da Flora do Brasil. Jardim Botânico do Rio de Janeiro. <http://floradobrasil.jbrj.gov.br/jabot/floradobrasil/FB92466>. 25 Nov. 2015

Kirk PM, Cannon PF, Minter DW, Stalpers JA. 2008. Ainsworth and Bisby's Dictionary of the Fungi. 10th. edn. Surrey, CABI Publishing.

Mittermeier SA, Fonseca GAB, Rylands AB, Brandon K. 2005. A Brief History of Biodiversity Conservation in Brazil. Conservation Biology 19: 601-607.

Motato-Vásquez V, Mello Gugliotta AM. 2014. Polypores from an Atlantic rainforest area in southeast Brazil: resupinate species. Brazilian Journal of Botany 37:175-185.

Motato-Vásquez V, Pires RM, Gugliotta AM. 2015a. Polypores from an Atlantic rainforest area in southeast Brazil: pileate species. Brazilian Journal of Botany 38: 149-164.

Motato-Vásquez V, Robledo GL, Gugliotta AM. 2015b. New records and geographic distribution map of Echinoporia Ryvarden (Schizoporaceae, Basidiomycota) species in the Neotropics. Check List 11: 1508.

Pires RM, Motato-Vásquez V, Gugliotta AM. 2015. Fuscoporia atlantica sp. nov., a new polypore from the Brazilian Atlantic Rainforest. Mycotaxon 130: 843-855.

Ryvarden L. 1991. Genera of polypores, nomenclature and taxonomy. Synopsis Fungorum 5. Oslo, Fungiflora.

Ryvarden L, Gilbertson RL. 1993. European Polypores Part 1. Oslo, Fungiflora.

Ryvarden L, Iturriaga T. 2010. Studies in Neotropical polypores 29. Some new and interesting species from the Andes region in Venezuela. Synopsis Fungorum 27: 78-91

Ryvarden L. 2014. Studies in Neotropical polypores 37. Some new and interesting species from tropical America. Synopsis Fungorum 32: 58-67.

Ryvarden L, Melo I. 2014. Poroid Fungi of Europe. Synopsis Fungorum 31. Oslo, Fungiflora.

Soares AMS, Sotão HMP, Medeiros PS, Gibertoni TB. 2014a. Riqueza de fungos poliporoides (Agaricomycetes, Basidiomycota) em uma floresta ombrófila densa da Amazônia, Amapá, Brasil. Boletim do Museu Mello Leitão 35: 5-18.

Soares AMS, Sotão HMP, Ryvarden L, Gibertoni TB. 2014b. Ceriporia amazonica (Phanerochaetaceae, Basidiomycota), a new species from the Brazilian Amazonia, and C. albobrunnea, a new record to Brazil. Phytotaxa (Online) 175-176. doi: 10.11646/phytotaxa.175.3.9

Sotão HMP, Campos EL, Costa SE, Melo AO, Azevedo JC. 2002 Basidiomycetes macroscópicos de manguezais de Bragança, Pará, Brasil. Hoehnea 29: 215-224.

Spirin W, Zmitrovich I, Malysheva V. 2007. New species in Junghuhnia (Polyporales, Basidiomycota). Annales Botanici Fennici 44: 303-308.

Watling R. 1969. Colour Identification Chart. Edinburgh, Her Majesty`s Stationery Office.

Westphalen MC, Reck MA, Silveira RMB. 2010. Ganoderma chalceum and Junghuhnia meridionalis: new records from Brazil. Mycotaxon 111: $11-18$

Westphalen MC, Reck MA, Silveira RMB. 2012. The genus Junghuhnia in Brazil. Nova Hedwigia 94: 209-220.

Westphalen MC, Reck MA, Silveira RMB. 2014. Studies on Wrightoporia (Basidiomycota) from southern Brazil. Phytotaxa 166: 94-100.

Wu Q, Thiers BM, Pfister DH. 2004. Preparation, preservation, and use of fungal specimens in herbaria. In: Mueller GM, Bills GF, Foster MF. (eds.) Biodiversity of Fungi. Burlington, Academic Press. p 23-36. 